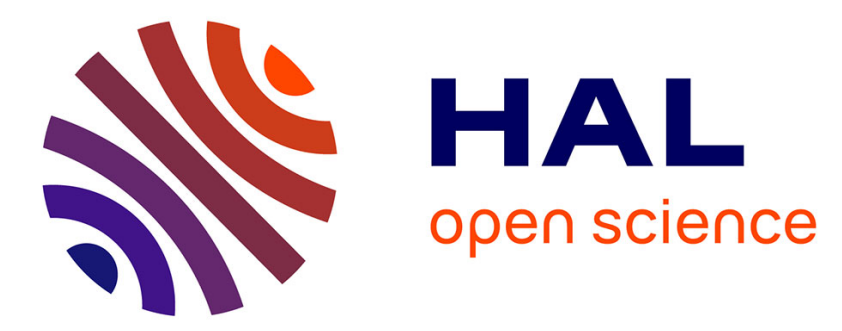

\title{
Neurotoxin stress-driven evolution in scallop genome
} Benjamin Marie

\section{To cite this version:}

Benjamin Marie. Neurotoxin stress-driven evolution in scallop genome. Toxicon, 2018, 150, pp.251252. 10.1016/j.toxicon.2018.06.071 . hal-03066065

\section{HAL Id: hal-03066065 https://hal.science/hal-03066065}

Submitted on 15 Dec 2020

HAL is a multi-disciplinary open access archive for the deposit and dissemination of scientific research documents, whether they are published or not. The documents may come from teaching and research institutions in France or abroad, or from public or private research centers.
L'archive ouverte pluridisciplinaire HAL, est destinée au dépôt et à la diffusion de documents scientifiques de niveau recherche, publiés ou non, émanant des établissements d'enseignement et de recherche français ou étrangers, des laboratoires publics ou privés. 


\section{Neurotoxin stress-driven evolution in scallop genome}

2

\author{
Dr. Benjamin MARIE \\ Unité mixte de recherche CNRS/MNHN « Molécules de communication et Adaptation des \\ micro-organismes ", Département Adaptation du vivant, Muséum National d'Histoire \\ Naturelle, 12 rue Buffon 75005 Paris, France \\ Email: bmarie@mnhn.fr
}

Understanding the molecular mechanisms underlying the resistance of organisms to specific environmental stressor is fundamental to understanding the deepest relationships between evolution and adaptation. Among environmental stressors, the exposure to contaminants and/or toxins could positively select specific and efficient adaptations providing advantages for resisting and surviving ${ }^{1}$. Few organisms, such as filter-feeding bivalves, can tolerate and accumulate remarkably high amounts of potent natural neurotoxins such as paralytic shellfish toxins (PSTs, produced by marine dinoflagellates $)^{2,3}$, although the specificity and molecular mechanism of this toxin resistance is not well apprehended.

Writting in Nature communications, Li et al. (2017) ${ }^{4}$ recently take us an additional step forward in understanding adaptation and evolution processes, reporting how scallop genome evolution can be driven by environmental and ecological pressures (Fig. 1). Among all the investigations performed by the authors in this manuscript - comprising also impressive datasets on byssus, adductor muscle and sophisticated eyes evolution - specific attention has been provided to describing specific molecular mechanisms aim at handling PST production by blooming phytoplanktonic micro-algae. Indeed, this manuscript admirably shows that scallop uses its hepatopancreas to accumulate neurotoxins and its kidney to transform them into even more toxic forms through an expansion of sulfotransferases in the genome and the specific regulation of their expression processes, probably also as deterrence against predation, while it achieves neurotoxin resistance through point-mutations in sodium channels.

This research begs the questions of how environmental stressors are susceptible to select specific adaptative events from genome evolution? How resistance mechanisms are co-evolving with the development of toxic pressures, such as environmental toxin production? Indeed, the examples of the molecular adaptations managing specific ecotoxicological pressures remain critically rare $^{1}$, and this manuscript push forward our understanding of how it may have emerged in the scallop genome.

To our knowledge, the original integrative approach developed by Li and co-workers, combining genomic, transcriptomic and ecotoxicologic investigations constitutes the first evidence of the effective influence of a natural ecotoxicological environmental stress (i.e. the proliferation of PST producing Alexandrium minutum) to the genome evolution (through the selection of gene-specific duplication or mutation mechanisms) increasing the overall organism resistance. $\mathrm{Li}$ and colleagues' method combining the characterization of the evolution pattern of sodium-channel mutations within eucaryote genomes and the investigation of the specific genome duplication events increasing the number of detoxication enzymes was originally intended for understanding the outstanding accumulation and transformation of PSTs within the scallop tissues.

The paper presents two sets of analyses performed at both genomic and molecular level for complementary toxicological investigations. The first genomic analysis reveals the 
expansion of the family of sulfotransferase detoxification enzymes in the scallop genome, together with the selection of specific point-mutations on Nav channel protein sequence that may explain the remarkable resistance of this organisms to the PSTs ${ }^{5-6}$. The second set of investigations takes things even further. Here, the authors comprehensively studied PST detoxification in the scallop by qualitatively and quantitatively analysing a variety of PSTs in six scallop organs, as well as global gene regulation measurements, across five time points after exposure to PST-producing micro-algae. This experiment suggests that, thanks to regulation events of the gene expression of detoxification enzymes, such as sulfo-transferases, the scallop hepatopancreas and kidney act as two major "centers" for toxin accumulation and transformation, respectively, which may also give the scallop a powerful deterrent against predation.

These findings highlight how "simple" mutations and expansions in one or two key genes may have profound implications for an organism's adaptation to the environment and the complex interactions with other organisms. This novel view combining genome and ecotoxicological investigations has broad implications for our understanding of how organisms respond to environmental stressors, and may be more widely applied in next future studies in this field.

\section{References}

1. Jost, M. C. et al. Toxin-resistant sodium channels: parallel adaptive evolution across a complete gene family. Mol. Biol. Evol. 25, 1016-1024 (2008).

2. Zhu, M., Zou, Y., Wu, R. \& Hall, S. Accumulation and depuration of paralytic shellfish poisons (PSP) in Chinese scallop Chlamys farreri. Acta Oceanol. Sin. 25,75-83 (2003).

3. Tian, H. et al. Comparative study on in vitro transformation of paralytic shellfish poisoning (PSP) toxins in different shellfish tissues. Acta Oceanol. Sin. 29, 120-126 (2010).

4. Li, Y. et al. Scallop genome reveals molecular adaptations to semi-sessile life and neurotoxins. Nature communications 8: 1721 (2017).

5. Bricelj, V. M. et al. Sodium channel mutation leading to saxitoxin resistance in clam increase risk of PSP. Nature 434, 763-7 (2005).

6. Choudhary, G., Yotsu-Yamashita, M., Shang, L., Yasumoto, T. \& Dudley, S. C. Jr. Interactions of the $\mathrm{C}-11$ hydroxyl of tetrodotoxin with the sodium channel outer vestibule. Biophys. J. 84, 287-294 (2003).

\section{Competiting interests}

The author declares no competing financial interests.

Figure 1. Specific evolution event driven by toxic stress pressure in Chlamis farreri's genome. 


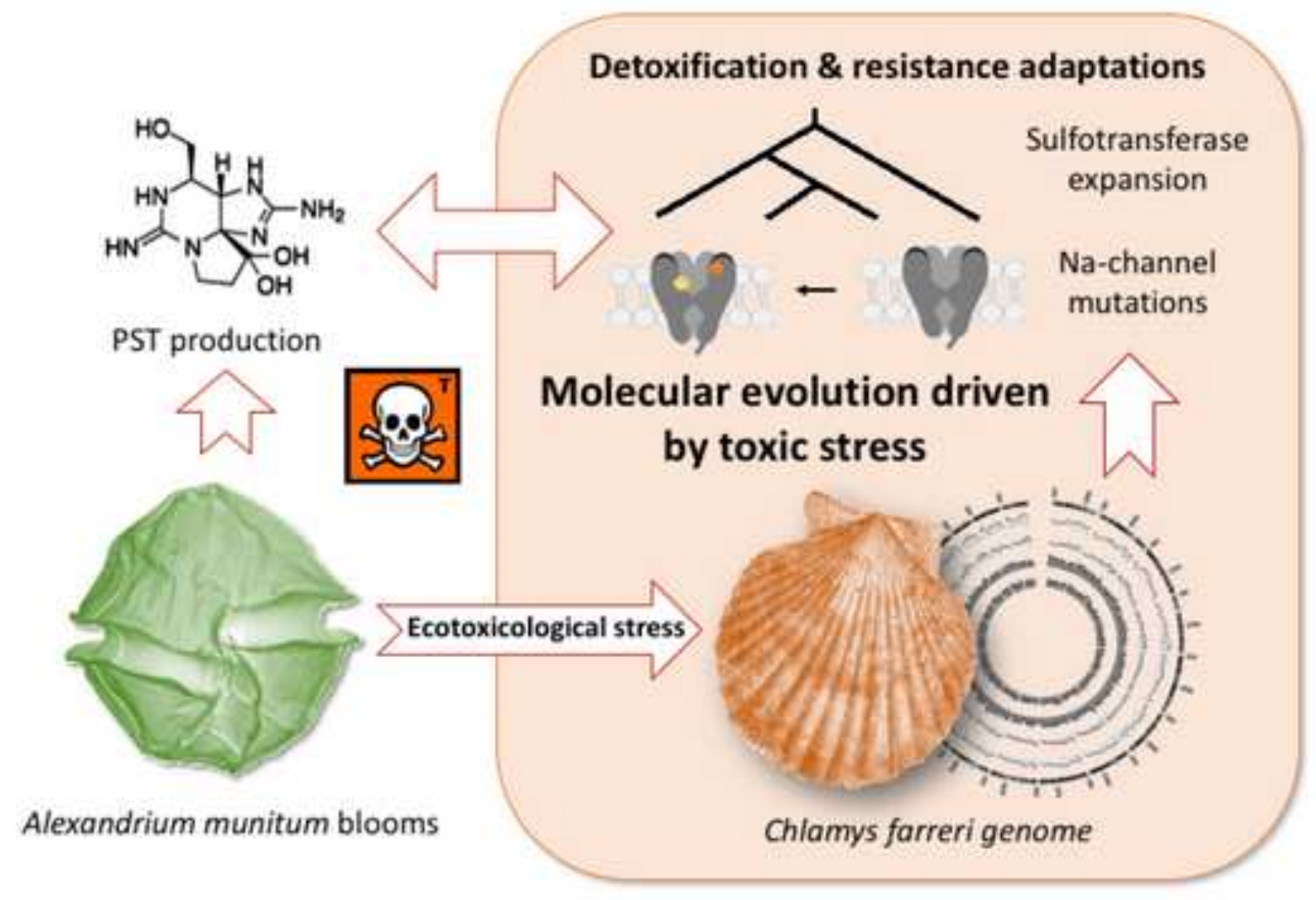

